\title{
Urgensi Penerapan Good Corporate Governance Pada Badan Usaha Milik Daerah Dalam Pengelolaan Minyak dan Gas Bumi Melalui Kepemilikan Participating Interest
}

\author{
Zahra Shafira Belanusa \\ Fakultas Hukum, Universitas Padjadjaran \\ Author’s email zahra16008@mail.unpad.ac.id \\ R. Kartikasari \\ Fakultas Hukum, Universitas Padjadjaran \\ Author’s email kartikasari@unpad.ac.id \\ Amelia Cahyadini \\ Fakultas Hukum, Universitas Padjadjaran \\ Author’s email amelia.cahyadini@unpad.ac.id
}

DOI: 10.23917/jjr.v10i1.9974

\begin{tabular}{|c|c|}
\hline $\begin{array}{l}\text { Submission } \\
\text { Track: }\end{array}$ & ABSTRAK \\
\hline 20 Januari 2020 & $\begin{array}{l}\text { Tujuan: Artikel ini menganalisis penerapan Good Corporate } \\
\text { Governance yang bertujuan agar mengetahui pengelolaan } \\
\text { minyak dan gas bumi oleh BUMD melalui kepemilikan } \\
\text { participating interest. }\end{array}$ \\
\hline Final Revision: & $\begin{array}{l}\text { Metodologi: Artikel ini merupakan artikel hukum yang } \\
\text { menggunakan metode penelitian hukum yuridis normatif yang } \\
\text { meletakkan hukum sebagai sebuah bangunan sistem norma } \\
\text { dikaitkan dengan praktik penerapan Good Corporate } \\
\text { Governance pada BUMD. }\end{array}$ \\
\hline Available online: & $\begin{array}{l}\text { Temuan: Hasil penelitian menunjukkan bahwa dengan } \\
\text { penerapan Good Corporate Governance pada BUMD, dapat } \\
\text { meningkatkan kinerja pimpinan BUMD sehingga berdampak } \\
\text { pada keberlangsungan bisnis secara berkesinambungan. }\end{array}$ \\
\hline $\begin{array}{l}\text { Corresponding } \\
\text { Author: } \\
\text { Zahra Shafira Belanusa } \\
\text { zahra16008@mail.unpad.ac.id }\end{array}$ & $\begin{array}{l}\text { Kegunaan: Artikel ini memberikan penjelasan bahwa dengan } \\
\text { penerapan Good Corporate Governance sejak dini pada BUMD, } \\
\text { merupakan salah satu langkah yang dapat membawa BUMD } \\
\text { pada tujuan yang akan dicapai dan dapat bergerak dengan baik } \\
\text { secara berkesinambungan. }\end{array}$ \\
\hline
\end{tabular}


Kebaruan/Orisinalitas: Penerapan Good Corporate Governance pada BUMD minyak dan gas bumi sangat menentukan dalam pengelolaan minyak dan gas bumi.

Keywords: Good Corporate Governance, Badan Usaha Milik Daerah, Perseroan Deerah, Minyak dan Gas Bumi, Participating Interest

\section{PENDAHULUAN}

Negara Indonesia memiliki berbagai kekayaan alam dan karakteristik minyak dan gas bumi dengan jumlah yang melimpah, maka dalam hal ini sangat penting bagi pemerintah Indonesia untuk mengembangkan sumber daya alam secara efektif (Rudi M. Simamora, 2000), hal ini sebagaimana tercantum di dalam Pasal 33 ayat (2) dan (3) UUD 1945. Minyak dan gas bumi merupakan sumber daya alam yang tidak terbarukan sehingga harus dikelola dengan sebaik-baiknya. Pengelolaan minyak dan gas bumi dibagi menjadi kegiatan usaha hulu dan hilir.

Dalam kegiatan usaha hulu minyak dan gas bumi, kegiatan eksplorasi dan eksploitasi merupakan kegiatan yang padat modal dan teknologi, serta berisiko tinggi dan penuh dengan ketidakpastian, namun memberikan keuntungan yang sangat besar (Madjedi Hasan, 2010), dengan banyaknya risiko dan sulitnya dalam melakukan kegiatan usaha hulu minyak dan gas bumi maka para pelaku usaha pada umumnya secara bersama-sama menyepakati Perjanjian Kerja Sama Operasi (selanjutnya disebut Perjanjian KSO) yang didalamnya tercantum pembagian besar hak pengelolaan terhadap suatu wilayah kerja atau biasa disebut participating interest.

Istilah participating interest ini mulai muncul setelah ditetapkannya Peraturan Pemerintah Nomor 35 Tahun 2004 tentang Kegiatan Usaha Hulu Minyak dan Gas Bumi (selanjutnya disebut PP Hulu Migas) yang mengatur mengenai pengelolaan industri minyak dan gas bumi dalam hal pembagian beban dan risiko dalam melaksanakan kegiatan usaha hulu. Pasal 34 peraturan ini menyatakan bahwa sejak disetujuinya rencana pengembangan lapangan yang akan di produksi dari suatu wilayah kerja, Kontraktor wajib menawarkan participating interest 10\% kepada Badan Usaha Milik Daerah (selanjutnya disebut BUMD). Berdasarkan hal tersebut daerah penghasil minyak dan gas bumi, melalui BUMD, diberikan 
wewenang berupa hak pengelolaan terhadap suatu wilayah kerja yang berada disekitar daerah penghasil minyak dan gas bumi.

Kepemilikan participating interest oleh BUMD ini telah tercantum di dalam Perjanjian KSO. Pemberian participating interest kepada BUMD telah diatur berdasarkan Peraturan Menteri Energi dan Sumber Daya Mineral Nomor 37 Tahun 2016 tentang Ketentuan Penawaran Participating Interest 10\% (Sepuluh Persen) Pada Wilayah Kerja Minyak dan Gas Bumi (selanjutnya disebut Permen ESDM Penawaran PI). Pemberian participating interest ini bertujuan agar daerah dapat benar-benar berpartisipasi dalam pengelolaan minyak dan gas bumi. Minyak dan gas bumi merupakan salah satu sumber daya alam yang tidak terbarukan sehingga dalam pengelolaannya membutuhkan sumber daya manusia yang mumpuni dan teknologi yang canggih.

Namun pada kenyataannya tingkat perekonomian masyarakat di daerah penghasil minyak dan gas bumi tidak mencapai pada taraf sejahtera. Kemiskinan di beberapa daerah penghasil minyak dan gas bumi masih dapat dikatakan tinggi. Permasalahan ini dikarenakan masalah pendanaan yang menjadi tantangan terbesar dalam bisnis hulu minyak dan gas bumi (Madjedi Hasan, 2010). Misalnya permasalahan pendanaan biaya operasi pada wilayah kerja minyak dan gas bumi yang ditanggung terlebih dahulu oleh Kontraktor, dalam hal ini BUMD diharuskan mengembalikan biaya operasi kepada Kontraktor yang diketahui biayanya sangat besar bagi BUMD. Di sisi lain, BUMD juga harus memisahkan bagian untuk keuntungannya. Lebih lanjut, pimpinan BUMD yang dirasa kurang kompeten terhadap bisnis di bidang hulu minyak dan gas bumi menjadikan hal ini salah satu masalah yang cukup membuat BUMD tidak dapat mengelola participating interest dengan baik.

Dengan adanya permasalahan tersebut, senyatanya pengelolaan minyak dan gas bumi oleh BUMD melalui kepemilikan participating interest perlu didukung dengan penerapan good corporate governance (Agus Dwiyanto, 2008), mengingat minyak dan gas bumi merupakan sumber daya alam yang tidak terbarukan, memerlukan teknologi yang canggih dan sumber daya manusia yang mumpuni sehingga diharapkan pengelolaan participating interest oleh daerah dapat dimanfaatkan dengan sebaik-baiknya sehingga dengan penerapan good corporate governance pada BUMD dapat mensiasati permasalahan yang ada dan dapat mengadakan hubungan yang baik dengan stakeholders guna meningkatkan produksi minyak dan gas bumi secara nasional. 
Tulisan ini menyoroti peran BUMD dalam pengelolaan minyak dan gas bumi melalui kepemilikan participating interest dan pentingnya penerapan prinsip good corporate governance pada BUMD sehingga dapat menghindari permasalahan-permasalahan yang sering terjadi dalam kegiatan bisnis hulu minyak dan gas bumi.

\section{METODOLOGI PENELITIAN}

Artikel ini membahas penerapan good corporate governance pada BUMD dalam pengelolaan minyak dan gas bumi. Artikel ini menggunakan metode penelitian yuridis normatif yang meletakkan hukum sebagai sebuah bangunan sistem norma (Fahmi M. Ahmadi, 2010). Metode pendekatan yang digunakan melalui asas-asas dan norma hukum yang terdapat dalam berbagai peraturan perundang-undangan, yurisprudensi, serta hukum kebiasaan yang berlaku dalam masyarakat melalui pendekatan kasus yang berkaitan dengan penelitian tentang penerapan good corporate governance dalam pengelolaan minyak dan gas bumi oleh BUMD. Bahan hukum yang digunakan, yaitu bahan hukum primer, sekunder, dan tersier.

\section{PEMBAHASAN}

\section{Badan Usaha Milik Daerah, Good Corporate Governance, Dan Participating Interest}

BUMD merupakan badan usaha yang seluruh atau sebagian besar modalnya dimiliki oleh daerah. Pendirian BUMD ini ditujukan untuk memberikan manfaat bagi perkembangan perekonomian daerah, menyelenggarakan kemanfaatan umum yang bermutu bagi pemenuhan hajat hidup masyarakat sesuai kondisi, karakteristik, dan potensi daerah yang bersangkutan berdasarkan tata kelola perusahaan yang baik, dan memperoleh laba atau keuntungan.

Mengacu pada ketentuan diatas maka senyatanya BUMD merupakan fasilitator yang berfungsi membantu pemerintah daerah untuk mendapatkan keuntungan sebesar-besarnya yang kemudian akan diberikan sebagian kepada pemerintah, dalam hal ini dapat menungkatkan pendapatan asli daerah sehingga berdampak pada meningkatnya kontribusi dalam pembangunan daerah.

Pada tahun 1997, di Indonesia mulai ramai diperbincangkan mengenai good corporate governance dikarenakan saat itu sedang terjadi krisis ekonomi. Akibat dari adanya krisis ekonomi tersebut, salah satunya terdapat banyak sekali perusahaan berjatuhan. Pengelolaan perusahaan secara tidak baik merupakan salah satu penyebab terjadinya krisis 
ekonomi di Indonesia (Indra Surya, 20006). Pada awalnya, good corporate governance di Indonesia diperkenalkan oleh Pemerintah Indonesia bersama dengan International Monetary Fund dalam rangka pemulihan ekonomi setelah krisis ekonomi.

Menurut pendapat Wahyudi Prakarsa, good corporate governance adalah suatu mekanisme administratif yang mengatur hubungan-hubungan antara manajemen perusahaan, komisaris, direksi, pemegang saham dan kelompok kepentingan (stakeholders) yang lain (Wahyudi Prakarsa, 2007). Selanjutnya menurut Sukrisno Agoes, good corporate governance atau tata kelola perusahaan yang baik adalah suatu sistem yang mengatur hubungan peran dewan komisaris, peran dewan direksi, pemegang saham, dan pemangku kepentingan lainnya (Sukrisno Agoes, 2011).

Mengacu pendapat diatas maka senyatanya hubungan antar stakeholders tersebut dapat diimplementasikan dalam bentuk berbagai aturan dan sistem sebagai suatu kerangka kerja yang diperlukan guna menentukan tujuan perusahaan dan pemantauan kinerja yang dihasilkan. Selain itu good corporate governance dapat dikatakan sebagai suatu proses yang transparan atas penentuan tujuan perusahaan, pencapaiannya, dan penilaian kinerjanya sehingga dapat membuat suatu sistem yang mengatur dan mengendalikan perusahaan (Ridwan Khairandy, 200). Dengan kata lain, penerapan good corporate governance dapat mendorong terciptanya persaingan yang sehat dan iklim usaha yang kondusif (Sutan Remy Sjahdeini, 1999).

Dalam menerapkan prinsip good corporate governance maka dibentuk Komite Nasional Kebijakan Governance untuk menyusun Pedoman Umum Good Corporate Governance di Indonesia yang pada pokoknya menguraikan prinsip-prinsip (Komite Nasional Kebijakan Governance, 2006):

a. Transparansi

Untuk menjaga obyektivitas dalam menjalankan bisnis, perusahaan harus menyediakan informasi yang material dan relevan dengan cara yang mudah diakses dan dipahami oleh pemangku kepentingan.

b. Akuntabilitas

Perusahaan harus dikelola secara benar, terukur dan sesuai dengan kepentingan perusahaan, tetap memperhitungkan kepentingan stakeholders. Prinsip ini merupakan prasyarat yang diperlukan untuk mencapai kinerja yang berkesinambungan.

c. Responsibilitas 
Perusahaan harus dapat mempertanggungjawabkan kinerjanya secara transparan dan wajar dengan kesesuaian didalam pengelolaan perusahaan terhadap peraturan perundang-undangan yang berlaku.

d. Independensi

Perusahaan harus dapat mewujudkan kemandiriannya dan tidak terpengaruh dengan pihak-pihak lainnya dalam melaksanakan usaha.

e. Kewajaran dan Kesetaraan

Prinsip ini dapat diwujudkan dengan adanya setiap kebijakan dari perusahaan yang memberi kesempatan yang sama bagi semua pegawai dan adanya sistem pengelolaan karyawan yang berbasis kompetensi.

Di dalam Undang-Undang Nomor 22 Tahun 2000 tentang Minyak dan Gas Bumi memang tidak menjelaskan secara rinci menganai participating interest di dalam kegiatan minyak dan gas bumi. Namun dalam PP Hulu Migas terdapat penjelasan mengenai participating interest, yaitu tercantum di dalam Pasal 33 ayat (1) PP Hulu Migas yang menjelaskan:

"Kontraktor dapat mengalihkan, menyerahkan, dan memindahtangankan sebagian dan seluruh hak dan kewajibannya (participating interest) kepada pihak lain setelah mendapat persetujuan menteri berdasarkan pertimbangan Badan Pelaksana”

Dalam hal ini terdapat pengaturan bahwa Kontraktor wajib menawarkan participating interest terlebih dahulu kepada BUMD, hal ini sebagaimana tercantum dalam Pasal 34 PP Hulu Migas dan Pasal 2 Permen ESDM Penawaran PI yang pada pokoknya menyatakan bahwa:

"Sejak disetujuinya rencana pengembangan lapangan yang pertama kali akan diproduksikan dari suatu Wilayah Kerja, Kontraktor wajib menawarkan participating interest $\mathbf{1 0 \%}$ (sepuluh per seratus) kepada Badan Usaha Milik Daerah.”

Keterlibatan daerah dalam pengelolaan minyak dan gas bumi bertujuan agar daerah ikut merasakan manfaat dari pengelolaan minyak dan gas bumi. Participating interest merupakan suatu hak dan kewajiban yang akan diperoleh BUMD. Hak yang akan diperoleh ini berupa hasil produksi minyak atau gas. Besarnya bagian perolehan hak tersebut setara dengan kewajiban yang harus dilakukan, yaitu berkewajiban untuk mengembangkan, mengoperasikan, dan melakukan pemeliharaan dalam kegiatan minyak dan gas bumi (Joko Purwanto, 2007). 
Penerapan Good Corporate Governance Pada BUMD Pengelola Minyak dan Gas Bumi

\section{Melalui Kepemilikan Participating Interest}

Dalam kegiatan usaha hulu minyak dan gas bumi memiliki ciri yang berbeda dalam hal struktur permodalan, risiko dan imbalan. Kegiatan hulu minyak dan gas bumi adalah kegiatan usaha yang padat modal, memiliki risiko dan teknologi yang tinggi serta penuh dengan ketidakpastian. Selama bertahun-tahun persoalan regulasi di bidang hulu minyak dan gas bumi di Indonesia adalah masalah ketidakpastian yang selalu berkaitan dengan tiga aspek utama, yaitu ketidakpastian regulasi, ketidakpastian ekonomi, dan proses administrasi atau birokrasi yang tidak sederhana (Madjedi Hasan, 2009).

Pengelolaan minyak dan gas bumi merupakan pelaksanaan suatu kegiatan yang membutuhkan biaya tinggi dan modal yang besar juga memiliki suatu kendala dalam melaksanakannya, yaitu memerlukan biaya sangat besar bahkan hingga lebih dari puluhan juta dollar sehingga sudah sangat sewajarnya dipertimbangkan oleh kontraktor dalam melaksanakan kegiatan usaha hulu minyak dan gas bumi (Madjedi Hasan, 2009). Dengan banyaknya biaya yang harus dikeluarkan, banyaknya risiko dan sulitnya dalam melakukan pengelolaan minyak dan gas bumi, maka para kontraktor pada umumnya sepakat untuk melakukan kegiatan usaha secara bersama-sama dengan cara membentuk suatu usaha patungan dalam sebuah Perjanjian KSO guna memudahkan para kontraktor dalam melakukan kegiatan minyak dan gas bumi di suatu wilayah kerja.

Selanjutnya sebagaimana uraian diatas, kontrakor wajib menawarkan hak pengelolaan atau participating interest 10\% kepada BUMD. Dalam hal ini kontraktor dan BUMD secara bersama-sama akan menyepakati Perjanjian KSO setelah bernegosiasi secara matang dan meyakini kegiatan usaha ini akan dijalankan dengan baik untuk menghindari permasalahan yang tidak diinginkan. Salah satunya mengenai sumber pembiayaan yang dibutuhkan oleh BUMD sebagai dana awal untuk mengelola participating interest pada wilayah kerja minyak dan gas bumi.

Pada umumnya terdapat beberapa model pembiayaan yang digunakan, salah satunya dengan skema kerja sama dengan kontraktor dilakukan dengan cara pembiayaan terlebih dahulu oleh kontraktor terhadap besaran kewajiban BUMD. Namun hal ini masih menjadi perdebatan dalam dunia hulu minyak dan gas bumi dikarenakan mekanisme seperti ini dalam pelaksanaannya dapat memberatkan kontraktor. 
Jika kontraktor melakukan pembiayaan terlebih dahulu terhadap kewajiban BUMD untuk mengelola suatu wilayah kerja minyak dan gas bumi, wajar bila kontraktor merasa khawatir atas dana yang dikeluarkan tidak dapat dikembalikan oleh BUMD, mengingat dana yang dapat dikatakan sangat besar dan bisnis hulu minyak dan gas bumi yang penuh dengan ketidakpastian, terutama jika menggunakan skema gross split pada Perjanjian KSO yang pada akhirnya tidak mengembalikan biaya operasi ketika hasil produksi telah didapatkan. Hal ini membuat kontraktor berfikir secara matang untuk melakukan pembiayaan terlebih dahulu.

Kemudian senyatanya masih saja memungkinkan jika kontraktor 'menanggung' terlebih dahulu biaya operasi BUMD untuk mengelola wilayah kerja minyak dan gas bumi, namun mengenai seberapa besar pengembalian setiap tahunnya ini belum terdapat kejelasan. Hal ini lah yang menjadi salah satu ketidakpastian regulasi di bidang hulu minyak dan gas bumi. Jika memang telah terdapat kepastian mekanisme terkait 10\% participating interest, kontraktor berharap mekanisme tersebut dapat dilakukan melalui mekanisme business to business dan yang terpenting pelaksanaannya tidak memberatkan kontraktor (Muhammad Yusuf Sihite, 2016).

Lebih lanjut terkait dengan pemberlakuan Permen ESDM Penawaran PI, daerah penghasil minyak dan gas bumi melalui BUMD belum tentu sepenuhnya diuntungkan. Mengacu pada Pasal 34 dan 35 (1) PP Hulu Migas yang menyatakan bahwa:

Pasal 34 PP Hulu Migas

"Sejak disetujuinya rencana pengembangan lapangan yang pertama kali akan diproduksikan dari suatu WiIayah Kerja, Kontraktor wajib menawarkan participating interest 10\% (sepuluh per seratus) kepada Badan Usaha MiIik Daerah.”

Pasal 35 (1) PP Hulu Migas

"Pernyataan minat dan kesanggupan untuk mengambil; participating jnterest sebagaimana dimaksud daIam PasaI 34 disampaikan oleh Badan Usaha Milik Daerah dalam jangka waktu paling lama 60 (enam puIuh) hari sejak tanggaI penawaran dari Kontraktor.”

Terlihat bahwa terdapat risiko berkurangnya keterlibatan BUMD dalam operasional wilayah kerja minyak dan gas bumi. Apabila diperhatikan kedua pasal tersebut dengan seksama, maka dapat diketahui bahwa participating interest merupakan hak yang dijalankan secara terbatas, khususnya mengenai jangka waktu 60 hari sejak ditawarkan oleh kontraktor (Muhammad Yusuf Sihite, 2016). Dengan kata lain, BUMD dalam hal ini harus menyatakan 
keputusannya apakah menerima tawaran participating interest tersebut atau tidak. Mengingat pengelolaan minyak dan gas bumi membutuhkan sumber daya manusia yang mumpuni dan tentunya membutuhkan modal yang sangat besar, maka senyatanya BUMD harus menyatakan sikap secara cepat dengan berbagai keterbatasan yang ada.

Terkait dengan syarat dan ketentuan di dalam Perjanjian KSO, sudah sepatutnya menegaskan hak BUMD untuk terlibat dalam operasional wilayah kerja minyak dan gas bumi walaupun dana hak kelola BUMD ditanggung oleh kontraktor. Hal inilah yang membuat kontraktor dapat menawar untuk mengurangi atau bahkan menghilangkan hak BUMD dalam perjanjian terpisah dari Perjanjian KSO. Skema pembiayaan terlebih dahulu oleh kontraktor ini menjadi disinsentif bagi bisnis minyak dan gas bumi jika tidak disiasati dan disosialisasikan secara benar.

Di sisi lain substansi participating interest yang diatur dalam PP Hulu Migas tidak mengatur secara spesifik mengenai BUMD yang memenuhi kualifikasi, baik dari segi hukum, kesiapan modal, kepemilikan, dan kemampuan untuk dapat bersaing dalam industri hulu minyak dan gas bumi (Muhammad Yusuf Sihite, 2016). Kemudian, bisnis di bidang hulu minyak dan gas bumi menuntut ketersediaan sarana \& prasarana, serta kualitas sumber daya manusia yang cukup memadai. Hal tersebut merupakan syarat pokok yang pada umumnya belum dapat dipenuhi oleh BUMD daerah penghasil minyak dan gas bumi sehingga perlu suatu upaya secara berkesinambungan untuk meningkatkan kualitas.

Minyak dan gas bumi sebagai sumber daya alam yang tidak terbarukan yang terkandung di dalam wilayah hukum Indonesia merupakan kekayaan nasional yang dikuasai oleh Negara Indonesia sehingga perlu dikelola dengan sebaik-baiknya. Pengelolaan minyak dan gas bumi oleh suatu badan usaha ini memiliki cakupan yang sangat luas dan berdampak pada perekonomian nasional (Rudi M. Simamora, 2000). Oleh karena itu setiap badan usaha yang mengelola sumber daya alam, khususnya perusahaan yang melakukan pengelolaan minyak dan gas bumi, harus menerapkan prinsip good corporate governance dalam kegiatan usahanya agar dapat meningkatkan nilai perusahaan dan kegiatan usahanya dapat meningkat secara berkesinambungan sehingga dapat ikut berkontribusi meningkatkan perekonomian nasional (Anton Sugiono, 2012).

Dengan semakin berkembangnya bisnis di bidang hulu minyak dan gas bumi, sering kali terjadi kasus pelanggaran good corporate governance pada BUMD pengelola minyak dan gas bumi di Indonesia. Salah satunya terkait dengan ketidakpastian aspek regulasi dan 
ekonomi yang membuat rancu antara para pihak. Misalnya terkait dengan permasalahan dalam aspek ekonomi, yaitu pembiayaan biaya operasi terlebih dahulu oleh kontraktor yang seharusnya BUMD berkewajiban membayar bagian biaya operasinya. BUMD yang sedari awal telah menyepakati akan mengembalikan biaya operasi kepada kontraktor, pada kenyataannya tidak dapat menepati janjinya tersebut. Hal ini dikarenakan pengelolaan participating interest pada BUMD tidak dilaksanakan dengan baik.

Hasil produksi BUMD terhadap pengelolaan minyak dan gas bumi, awalnya bisa saja dikatakan mencapai atau bahkan melebihi target. Pencapaian ini seharusnya dapat dipertahankan jika BUMD dapat mengelola minyak dan gas bumi dengan baik secara berkesinambungan. Namun ternyata dalam beberapa kasus yang menimpa BUMD, pngelolaan ini dilaksanakan secara tidak baik sehingga tidak dapat melanjutkan kegiatan usahanya secara berkesinambungan. Terdapat beberapa permasalahan yang menimpa BUMD, salah satunya terkait kenaikan gaji yang sangat besar yang diberikan kepada pimpinan-pimpinan BUMD tanpa adanya persetujuan RUPS, Hal ini tentunya menjadi sangat janggal dan berdampak pada ketidakberdayaan BUMD untuk mengembalikan biaya operasi kepada kontraktor.

Pemicu awal permasalahan ini yaitu ketidakpatuhan BUMD terhadap Perjanjian KSO yang telah disepakatinya dengan kontraktor. Dalam hal ini BUMD berkewajiban mengelola minyak dan gas bumi dengan baik dan dapat dilaksanakan secara berkesinambungan. Pengurus BUMD, terutama pimpinan, harus memiliki integritas yang baik, kinerja yang baik, dan tentunya pengetahuan terkait pengelolaan minyak dan gas bumi yang mumpuni. Akan sangat disayangkan jika ternyata setelah diberikan participating interest, BUMD belum menyiapkan sumber daya manusia yang mumpuni dan teknologi yang cukup baik sehingga berdampak pada pengelolaan minyak dan gas bumi yang tidak memuaskan.

Mengacu pada hal tersebut, kontraktor perlu mempertimbangkan kesanggupan dan kepatuhan BUMD dalam melaksanakan ketentuan-ketentuan sebagaimana telah disepakati bersama. Hal ini perlu didukung dengan pemimpin BUMD yang paham betul terkait bisnis di bidang minyak dan gas bumi karena dengan memiliki pemimpin dan sumber daya manusia yang mumpuni niscaya pengelolaan participating interest di daerah akan berjalan dengan baik. Mengingat bahwa tujuan pemberian participating interest $10 \%$ di wilayah kerja minyak dan gas bumi kepada BUMD selain ditujukan untuk peningkatan pendapatan 
asli daerah, juga untuk transparansi dan keterbukaan dalam pengelolaan wilayah kerja tetap terjaga antara kontraktor dengan pemerintah daerah yang diwakili oleh BUMD.

Selain itu juga dapat memastikan agar pengelolaan atas wilayah kerja memberikan dampak nyata langsung kepada daerah penghasil minyak dan gas bumi agar lebih berkembang. Manfaat lainnya adalah mendapatkan hak atas bagian minyak dan gas buminya sehingga dapat menjaga dan memastikan ketahanan energi di daerah penghasil energi. Selanjutnya, BUMD tetap dapat memperoleh informasi dari pihak pertama mengenai wilayah kerja. Tujuannya agar bisa mendorong daerahnya terlibat atau mengikuti bisnis turunan dari suatu wilayah kerja dengan tetap memenuhi ketentuan yang berlaku.

Di sisi lain, permasalahan BUMD dalam aspek regulasi terkait keterbatasan waktu untuk menyatakan keputusan menerima atau menolak pemberian participating interest sebesar $10 \%$, senyatanya hal tersebut tidak terlalu bermasalah jika BUMD sedari awal telah menyiapkan segala sesuatunya. Dalam hal ini terdapat kegiatan pra participating interest yang merupakan kegiatan awal perkenalan mengenai pengelolaan minyak dan gas bumi, transfer knowledge dari kontraktor kepada BUMD, keperluan tenaga ahli, teknologi, dan recruitment karyawan yang sesuai dengan kriteria. Kegiatan ini dapat dilaksanakan beberapa kali sebelum akhirnya disepakati pemberian participating interest oleh kontraktor kepada BUMD sebagaimana tertuang di dalam Perjanjian KSO.

Dengan perencanaan yang sangat matang, sumber daya manusia dan pimpinan yang paham terkait pengelolaan minyak dan gas bumi, dan keyakinan untuk mengelola BUMD dengan baik dan berlangsung secara berkesinambungan maka senyatanya tidak ada keraguan untuk menyepakati penerimaan participating interest 10\% pada BUMD walaupun dengan keterbatasan waktu yang ada. Regulasi pada kegiatan usaha hulu minyak dan gas bumi memang sangat banyak dan saling tumpang tindih. Namun para pihak, dalam hal ini kontraktor dan BUMD, harus dengan cermat dan teliti untuk mensiasati keberlangsungan usaha dengan tetap memperhatikan peraturan perundang-undangan yang berlaku.

Mengacu pada keseluruhan uraian di atas, maka prinsip good corporate governance yang harus diterapkan oleh BUMD dalam mengelola minyak dan gas bumi, meliputi:

\section{a. Transparansi}

Perlu dilakukannya penyediaan informasi dengan jelas kepada stakeholders terhadap segala kegiatan yang telah dilaksanakan agar stakeholders dapat mengetahui segala 
sesuatu terkait pengelolaan minyak dan gas bumi oleh BUMD penerima 10\% participating interest.

b. Akuntabilitas

BUMD harus selalu berusaha untuk berpartisipasi dan berperan aktif dalam perbaikan kinerja guna mencapai kinerja yang berkesinambungan. Hal tersebut senyatanya telah berusaha diimplementasikan sedari awal sehingga seterusnya dalam melakukan kegiatan bisnis sehari-hari telah terintegrasi kerangka sistem yang telah dibangun untuk masa depan perusahaan yang berlandaskan good corporate governance

c. Responsibilitas

BUMD harus menerapkan prinsip ini sejak rencana akan diberikannya participating interest. BUMD harus selalu berusaha mengoptimalkan dukungan pemerintah daerah dan legislatif serta stakeholders dalam rangkaian proses untuk mendapat participating interest di wilayah kerja minyak dan gas bumi. Dalam hal ini BUMD harus mematuhi aspek hukum bisnis dan ketentuan yang ada untuk melindungi kepentingan perusahaan dan menghindari pelanggaran terhadap peraturan dan perundang-undangan. Sebelum disepakatinya Perjanjian KSO, terlebih dahulu BUMD sebagai pihak penerima participating interest meminta dukungan dari pemerintah setempat untuk dapat mempermudah dan mempercepat proses penerbitan perizinan yang diperlukan dalam pelaksanaan kegiatan di wilayah kerja minyak dan gas bumi, termasuk salah satunya dukungan pemerintah setempat untuk membantu penyelesaian permasalahan yang timbul selama pelaksanaan kegiatan di wilayah kerja minyak dan gas bumi dengan berdasarkan Permen ESDM Penawaran PI.

d. Independensi

BUMD sebagai pihak yang berhak mengelola minyak dan gas bumi dengan kepemilikan participating interest, harus memiliki ketegasan dalam pelaksanaan kegiatannya dengan tidak mudah untuk didominasi pihak manapun untuk melakukan pengelolaan minyak dan gas bumi yang telah menjadi hak dari BUMD itu sendiri.

e. Kewajaran dan Kesetaraan

Dalam melakukan kegiatan usahanya, sudah sepatutnya BUMD memerlukan sumber daya manusia untuk mencapai tujuan dari pengelolaan minyak dan gas bumi. BUMD harus memperlakukan seluruh karyawan dengan pinsip kesetaraan. Tidak hanya itu, 
tetapi dalam masa perekrutan karyawan, BUMD juga harus membuka kesempatan pada seluruh pihak yang memenuhi kualifikasi.

\section{KESIMPULAN}

Penerapan prinsip good corporate governance pada BUMD dalam pengelolaan minyak dan gas bumi akan meningkatkan hubungan baik dengan stakeholders, pengelolaan kegiatan usaha dengan berlandaskan peraturan perundang-undangan, kegiatan usaha yang berlangsung secara berkesinambungan, dan tentunya mendatangkan keuntungan yang besar. Minyak dan gas bumi merupakan salah satu sumber daya alam yang tidak terbarukan. Untuk mengelola minyak dan gas bumi diperlukan dana yang sangat besar, sumber daya manusia yang mumpuni, teknologi yang canggih, dan tenaga ahli yang memahami pengelolaan minyak dan gas bumi dengan baik sehingga mendapatkan hasil produksi sesuai dengan yang ditargetkan.

Dilatarelakangi kompleksitas pengelolaan minyak dan gas bumi, maka sangat diperlukan penerapan prinsip good corporate governance untuk menunjang kegiatan usaha dengan pengelolaan BUMD secara baik, benar, dan tentunya dapat memberikan hasil produksi yang maksimal. Penerapan prinsip good corporate governance sejak dini, merupakan salah satu langkah yang dapat membawa suatu perusahaan pada tujuan yang akan dicapai dan dapat bergerak dengan baik secara berkesinambungan. Pentingnya penerapan prinsip good corporate governance adalah menghindari permasalahanpermasalahan yang tidak diinginkan dikemudian hari, terutama setelah penandatanganan Perjanjian KSO oleh para pihak.

\section{REFERENCES}

Ahmadi, Fahmi M, (2010), Metode Penelitian Hukum, Jakarta: Lembaga Penelitian UIN Syarif Hidayatullah.

Agoes, Sukrisno, (2011), Etika Bisnis dan Profesi, Jakarta: Salemba Empat.

Dwiyanto, Agus, (2008), Mewujudkan Good Corporate Governance Melalui Pelayanan Publik, Yogyakarta: Gadjah Mada University Press.

Surya, Indra dan Ivan Yustiavandana, (2006), Penerapan Good Corporate Governance, Jakarta: Prenada Media Group. 
Komite Nasional Kebijakan Governance (KNKG), (2006), Pedoman Umum Good Corporate Governance Indonesia, Jakarta: Komite Nasional Kebijakan Governance.

Hasan, Madjedi, (2009), Kontrak Minyak dan Gas Bumi Berazas Keadilan dan Kepastian Hukum, Jakarta: Fikahati Aneska.

Hasan, Madjedi, (2010), Tinjauan Yuridis Kontrak Minyak dan Gas Bumi di Indonesia, Makalah Disampaikana Pada Training on The Oil and Gas, Jakarta, 7 Juni 2010.

Khairandy, Ridwan dan Camelia Malik, (2007), Good Corporate Governance Perkembangan Pemikiran dan Implementasinya di Indonesia dalam Perspektif Hukum, Yogyakarta: Total Media.

Purwanto, Joko, (2007), Minyak Tidak Untuk Rakyat: Sejarah \& Participating Interest Industri Minyak dan Gas Bumi Blok Cepu, Makalah Disampaikan Pada Seminar Transparansi di Bidang Industri Ekstraktif di Indonesia, Jakarta, 13 Juni 2007.

Prakarsa, Wahyudi, (2007), Corporate Governance: Suatu Keniscayaan, dalam Jurnal Reformasi Ekonomi Vol 1 No. 2. 2007.

Simamora, Rudi M, (2000), Hukum Minyak dan Gas Bumi. Jakarta: Djambatan.

Sihite, Muhammad Yusuf, (2016), Kaji Ulang Penawaran Participating Interest Bagi Badan usaha Milik Daerah (BUMD) Dalam Industri Hulu Minyak dan Gas Bumi (Migas), dalam Jurnal RechtsVinding: Media Pembinaan Hukum Nasional, 26 Januari 2016.

Sjahdeini, Sutan Remy, (1999), Pengembangan Fungsi Pengawasan Menuju Good Corporate Governance Pada Milenium Baru, Makalah disajikan pada Seminar yang diselenggarakan Yayasan Pendidikan Internal Auditor (YPAI), Graha Sucofindo, Jakarta 29 September 1999.

Sugiono, Anton, (2012), Analisis Good Corporate Governance Terhadap Kinerja Keuangan Perusahaan, dalam Jurnal Majalah Ilmiah Informatika Vol. 3 No. 1. Januari 2012. 